\title{
A Lacanian Reading of Hamlet: The Mourning Subject of Desire
}

\author{
Norman Marín Calderón \\ Escuela de Lenguas Modernas \\ Universidad de Costa Rica
}

\begin{abstract}
This paper analyzes Shakespeare's Hamlet as an interwoven drama between desire and death. Hamlet takes his desire as an enigma because he does not know what to do with it nor when to act accordingly. For Lacan, Hamlet is trapped in the alienated webs of the capitalized Other who, unconsciously, points him what and how to desire. At this crossroads, Hamlet appropriates his (M)other Gertrude and his beloved Ophelia in order to place them as the objects of his desire, that is, as his signified phallus. Therefore, for Lacan, Hamlet is the tragedy of desire.
\end{abstract}

Key words: Hamlet, Ophelia, mother, mourning, desire, phallus, object, Jacques Lacan, William Shakespeare

\section{Resumen}

Este ensayo analiza la obra de Shakespeare, Hamlet, como el entresijo que existe entre deseo y muerte. Hamlet toma su deseo como un enigma porque no sabe qué hacer con él ni cuándo actuar en conformidad. De acuerdo con Lacan, Hamlet está atrapado en las redes alienantes del Otro, quien, inconscientemente, le indica qué y cómo desear. En esta encrucijada, Hamlet toma a su madre Gertrudis y a su amada Ofelia con el fin de elevarlas al objeto de su deseo, a saber, su falo significante. Por lo tanto, para Lacan, el drama de Hamlet es la tragedia del deseo.

Palabras claves: Hamlet, Ofelia, madre, duelo, deseo, falo, objeto, Jacques Lacan, William Shakespeare

Doubt thou the stars are fire; Doubt that the sun doth move; Doubt truth to be a liar; But never doubt I love. William Shakespeare, Hamlet 
$H$ amlet, Prince of Denmark (circa 1603) by William Shakespeare (1564-1616) is one of the most analyzed dramatic texts in literary history. Interpretations go from political and religious to philosophical and psychological: The psychoanalytic criticism is one of them. All these analyses stem from the fact that an enigma is milling around the Shakespearean drama. This enigma revolves around Hamlet's inability to act: He cannot kill Claudius - the killer, the incestuous, the usurper. He cannot love Ophelia, either. That is, Hamlet cannot desire until it is too late to act accordingly. It is only at the end of the play, when he finally "discovers" his desire by fighting Laertes in the digged hole where Ophelia lies dead. In a sense, this play is about the desire of a man who questions if "being" or "not being" is related to death. Am I alive or dead? That would be the key question to be answered along the play.

In the field of psychoanalysis, Sigmund Freud, Ernest Jones, Otto Rank, and Jacques Lacan, to name a few, have analyzed Hamlet from different perspectives, especially as a drama where a subject is trapped in his own neurosis due to the imposing intricacies of his Oedipus complex. In fact, for Freud, Hamlet is a rewriting of Sophocles' Oedipus Rex. In The Interpretation of Dreams, Freud exposes this:

The play [Hamlet] is built up on Hamlet's hesitations over fulfilling the task of revenge that is assigned to him; but its text offers no reasons or motives for these hesitations and an immense variety of attempts at interpreting them have failed to produce a result. [...] The answer, once again, is that it is the peculiar nature of the task. Hamlet is able to do anythingexcept to take vengeance upon the man who did away with his father and took the father's place with his mother, the man who shows him the repressed wishes of his own childhood realized. Thus the loathing which should drive him on to revenge is replaced by self-reproaches, by scruples of conscience, which remind him that he himself is literally no better than the sinner whom he is to punish. Here I have translated what was bound to remain unconscious in Hamlet's mind. (Freud 264)

Indeed, Hamlet is a man dominated by excesive thinking which provokes certain paralysis when faced with a situation that calls for taking action. Or more precisely, Hamlet can act, except in the commended moment of true action and desire - to kill a man, Claudius, who has murdered his father and has taken his place in his mother's marital bed. Thus, Hamlet is shaped as such a character because of his impending mourning of his father and the incestuous disgust with his mother.

Likewise, for Lacan, Hamlet embodies the conundrum of procrastination at the moment of avenging his father, the king, and confronting his mother Gertrude. Hamlet hence suffers from doubts. To analyze Hamlet from a psychoanalytic perspective, we will especially base our analysis on Lacan's Seminar VI-Desire and the Interpretation of Desire (1959) as translated and established 
by Shoshana Felman in "Desire and the Interpretation of Desire in Hamlet ("Desire")." According to Lacan, Hamlet can be read as the story of something that must be done but can never be materialized. This text is indeed considered the drama of such postponement. In sum, Shakespeare's play deals with a "hole" that, after all, marks the non-realization of an act-Hamlet's revenge for his father's death.

Consequently, according to what unfolds in Shakespeare's drama, desire is the "Thing" to be placed at the heart of psychoanalytic theory and technique. The structural analysis of Hamlet leads the reader to situate the meaning and interpretation of desire as the contraption that mobilizes the characters' positions and the succession of dramatic events. As previously mentioned, for Lacan, Hamlet is the drama of desire. Desire is here understood as the "lack" that moves a subject to want more. Desire is defined as the lack that constitutes a speaking subject as such. The object that causes that desire in motion is the "phallus." Contrary to Freud, Lacan conceives the phallus not as the male organ, but as the primordial signifier of completeness and full self-realization-it is the phallic signifier, after all. In "The Signification of the Phallus," Lacan explains:

In Freudian doctrine, the phallus is not a fantasy, if by that we mean an imaginary effect. Nor is it such an object (part-, internal-, good, bad, etc.) in the sense that this term tends to accentuate the reality pertaining in a relation. It is even less the organ, penis or clitoris, that it symbolizes. [...] the phallus is a signifier. (579)

According to Lacanian theory, the phallus is not a fantasy, nor a partial object, nor a physical organ. The phallus stands for the signifier of what the omnipotent mother is missing and that which the child can relate to, so he can be identified as the object that the mother is lacking.

There exists an intrinsic relationship between the subject of language and his object of desire which is represented in Lacan by the "Formula of Fantasy", that is, a type of framed subjective ghost (specter) that rules and structures any subject's life- $\$ \diamond a$. In that respect, Lacan explains the importance of the formula of fantasy in relation to the emergence of desire in a subject:

I express the general structure of the fantasy $\$ \diamond a$, where $\$$ is a certain relationship of the subject to the signifier-it is the subject as irreducibly affected by the signifier-and where $\diamond$ indicates the subject's relationship to an essentially imaginary juncture, designated by $a$, not the object of desire but the object in desire [the one that causes desire to happen] [...]. This is our starting point: through his relationship to the signifier, the subject is deprived of something of himself, of his very life, which has assumed the value of that which binds him to the signifier. The phallus is our term for the signifier of his alienation in signification. When the subject is deprived of this signifier, a particular object becomes for him an object of desire. This is the meaning of $\$ \diamond a$. ("Desire" 22-23) 
This formula can be read as "the divided subject in relation to the object that causes his or her desire"- the small object $(a)$. Fantasy is the pointer of desire since desire is processed only through fantasy. Here the small letter $(a)$ names the impossible object of desire-the phallic signifier of lack. In Hamlet, Gertrude and Ophelia will come to occupy, at different levels and under several circumstances, this phallic place.

On the same hand, according to Kenneth Reinhard and Julia R. Lupton, the formula of fantasy, as described here, designates the relationship between a split subject alienated by language to a specific object that promises to compensate for that fundamental lack: "At this point in Lacan's thought, the $a$ functions as the imaginary substitute for the real substratum of living being forever blocked by the symbolic accession to language. Here Lacan associates the barring of the subject with the phallus, the castrating mark of linguistic substitution, which guarantees that the object exists only in desire, [...]" (50). Particularly, Lacan accentuated that the subject is always represented in fantasy, as in the dream, in a more or less obvious way. In fact, the fantasy stages a certain relation and mode of interaction between the barred subject $(\$)$ and the object of desire $(a)$. Thus conceived, fantasy is a complex structure, a kind of scenario, as opposed to the simple hallucination of an object.

Concurring with Lacan, Hamlet is "the tragedy of desire" for three reasons. First, Hamlet does not act in time, he is always "delayed" due to the dependence of his desire on the desire of the Other, especially the (M)Other's. Second, Ophelia substitutes for Hamlet's phallus insofar as she stands as the lost object that can only be attained when she is dead. In this sense, Ophelia becomes Hamlet's "impossible" object of desire since she is dead. And finally, mourning is the other theme that is incarnated at the end of play when Hamlet is able to mourn the loss of his phallic signifier-Ophelia.

The structure of Hamlet is held by "his situation of dependence with respect to the desire of the Other ("Desire" 17). Even more, he is truly attached to the desire of his m-other. His dependence to her desire keeps Hamlet from choosing between his idealized dead father and the "degraded, despicable object Claudius" ("Desire" 12). Hamlet is constantly wondering: what is my mother's desire? Or more precisely, what does she want from me? (Che vuoi?). Consequently, this questioning about the desire of the (m)Other keeps Hamlet out of action since he is structured solely by the desire of the Other. In "Hamlet and the Desire of the Mother", Jean-Michel Rabaté asserts that:

The source of Hamlet's inhibition does not stem from his desire for his mother, but from his own 'fixation' within his mother's desire. The shift from a subjective genitive (where 'mother's desire' means 'desire for the mother') to an objective genitive ('mother's desire' as her 'desire for another man') has never worked better; it is a 'dialectical' mechanism indeed, whose flexibility is nevertheless limited since it refutes the old Oedipian psychology. (61)

Lacan insists that Hamlet "is constantly suspended in the time of the Other, throughout the entire story until the very end ("Desire" 17), which is, after all, 
the time of death. For instance, Hamlet is incapable of killing Claudius because he is praying, an untimely time to kill him since it is the hour of the Other:

HAMLET. Now might I do it pat, now 'a is a-praying

And now I'll do't. And so 'a goes to heaven, And so am I revenged. That would be scanned. (3. 3. 85)

Thus, the tragedy of Hamlet takes place at the hour of the capitalized Other, at the exact moment, and until the very end, when it is Hamlet's hour, the time of his looming death. Once again, this trajectory of desire denotes the concept of phallus: "If Hamlet's action is delayed because it is the hour of the Other, because he is subject to the desires of the others, this becomes possible only because he is subject to the signifier of these desires, and this signifier is the phallus" (Muller 150). In sum, desire is "something" that remains outside the subjective being; it is the desire of others, whose recognition he seeks, and the desire that is linked to the subject who speaks because he has been trapped by the law of language and the signifier itself. To this point, Hamlet's essential vacillation and postponement lies in the field of Gertrude's ambiguous desire for which Hamlet is "too much in the mother" ("Desire" 15).

As remarked before, Hamlet is dominated by his Mother as a big Other, that is, as the primordial subject of his demand. The dependence of his desire on the Other constitutes the permanent dimension of Hamlet's drama. For Rabaté, "Hamlet's inhibition will thus be seen to stem from his archaic desire for his mother, but more because the paralysis derives from his fixation with the riddle of Gertrude's desire for another man, whether his uncle or father" ("Psychoanalysis Applicable and Inapplicable" 59). In that sense, according to Lacan, Hamlet's enigma is Gertrude. Lacan affirms that "the omnipotence of which we are always speaking in psychoanalysis is first of all the omnipotence of the subject as subject of the first demand, and this omnipotence must be related back to the mother" ("Desire" 12). In relation to the desire of the mother, Lacan bases his analysis on the "moralistic" scene where Hamlet tries to convince his mother to abandon Claudius: "O, throw away the worser part of it, And live the purer with the other half. Good night_-but go not to my uncle's bed. Assume virtue, if you have it not" (3. 4. 91).

In this scene, Hamlet cannot accept that the omnipotence of her mother, as the first object of his demand, is now a woman-a woman, not a mother anymore. Lacan asserts that Hamlet's mother is a real genital woman who cannot be accepted by her son. Hamlet is now overwhelmed by the sexual enjoyment that his mother experiences: He cannot stand that anymore. That is why, somehow, Hamlet gives up and tells his mother again: "Not this, by no means, that I bid you do: Let the bloat King tempt you again to bed, Pinch wanton on your cheek, call you his mouse, and let him, for a pair of reechy kisses, Or paddling in your neck with his damned fingers, Make you to ravel all this matter out, That I essentially am not in madness, But mad in craft" (3. 4. 92).

On the other hand, Claudius-Hamlet's incestuous and shameless bandit exhibits the "real" phallus enjoyed by Gertrude, which represents the adulterous 
union outrageously literalized in the enigmatic dialogue there is between Hamlet and his step-father:

HAMLET. Farewell dear mother.

CLAUDIUS. Thy loving father, Hamlet.

HAMLET. My mother. Father and mother is man and wife, man and wife is one flesh; so my mother. (4. 3. 99)

Claudius is acting here in the place of Gertrude, that is, in the place of the phallus - cause of Hamlet's desire. We can see the terms in which whether Gertrude or Claudius can become that important phallic signifier insofar they desire and have access to what Hamlet has been denied of.

Between the phallic object, desire and death, Hamlet can only kill Claudius when the act of revenge becomes a kind of retaliation for his own death. Hamlet fails to abscond the ensnares of his own Ego in which he becomes a coward subject in relation to his desire. In this respect, in Jacques Lacan: The Death of an Intellectual Hero, Stuart Scheneiderman declares:

When he [Hamlet] does it [act], it is too late, his act no longer means anything, it no longer has its ethical edge. The murder of Claudius is an afterthought, which Hamlet, as Lacan said, can only accomplish when he is dying, when he will not have to bear responsibility for his act. Even more important is the fact that Hamlet acts when he learns that the wretched Claudius is responsible for Hamlet's impending death. Hamlet can avenge himself because he is an egoist to the end, especially at the end. With his dying breath he asks Horatio to tell his story. [...] Hamlet is clearly a failure-he cannot act on his desire, he can only perform the act he is obliged to perform when it is no longer his desire-and his success is to convince the audience that it is no failure at all, that we can still love him. (153-54)

Lacan's analysis rests in the liaison between Hamlet and Gertrude and not on Hamlet's relation to Claudius. In sum, the desire of the mother is accountable for situating Hamlet's time out of juncture. This can be elucidated by Lacan's matheme $\mathbf{S}(\mathbb{A})$ which stands for the signifier of the ultimate inconsistency of the Other; that is, the unfathomable countenance of Gertrude's desire: S (A) "marks the absence of some final guarantor or 'Other of the Other' that could answer the che vuoi? [what do you want] question that every child addresses to the Other" (Sharpe, “To Be or Not ...” 105).

Now, if Gertrude is the phallic object for Hamlet's desire, Ophelia represents the object that "causes" (produces, initiates, triggers) his desire. In this sense, Ophelia constitutes Hamlet's objet petit (a). Lacan implies that "with the respect to the object $(a)$, the object is the object of desire only by virtue of being the end-term of the fantasy. The object takes the place, I would say, of what the subject is-symbolically-deprived of" ("Desire" 15). As substitute for the abandoned phallus, the small object $(a)$ carries a relation to the unconscious, 
the magnified capitalized Other, but falls short of ever taking its place. Properly speaking, Ophelia is not the object of Hamlet's desire (that is the all-powerful Mother), but rather the object in his desire, the cause of it. John P. Muller asserts that "it is more proper to speak of her [Ophelia], like the imaginary phallus, as the cause of desire and the 'lure of being', giving Hamlet a delusion of being more than he is" (151). Ophelia, as a site for desire, changes along the drama. First in place, Ophelia-the other of love, the phallisized partenaire, will become and represent a different object of desire once she dies. Hamlet takes Ophelia as his object petit $(a)$ in three different ways.

First, at the beginning of the play, Hamlet experiences certain distance from Ophelia precisely because she represents for him a trigger for his desire. He needs to move away from her because he does not want to "know" anything about his own desire. This is for Lacan a moment of "estrangement" marked by "the distance from the object that Hamlet takes in order to move on to whatever new and henceforth difficult identification, his vacillation in the presence of what has been until now the object of supreme exaltation" ("Desire" 21). This is obvious when Ophelia describes how Hamlet enters her premises in an unkempt state:

OPHELIA. He [Hamlet] took me by the wrist and held me hard;

Then goes he to the length of all his arm,

And with his other hand thus o'er his brow

He falls to such perusal of my face

As 's would draw it. Long stayed he so. [...]

For out o' doors he went without their helps,

And to the last bended their light on me. (2. 1. 38-39)

At this moment, Hamlet becomes a depersonalized subject who is "completely null and dissolved as a love object" ("Desire" 22). Once, Hamlet said to his beloved: "I did love you once" (3. 1. 65); however, in the scene mentioned afore, Hamlet treats Ophelia with derision and cruel belligerence. What kind of love is that?

The second manner Hamlet addresses Ophelia as his object of desire is not only in terms of cruel aggression towards the object, but as the "destruction and loss of the object" ("Desire" 23). Ophelia is turned here into an object that is not placed in the symbolic order but rather appears in the real, no longer being part of his unconscious fantasy. At this stage, Ophelia is not Hamlet's object of desire because he rejects her (it) with all the forces of his being. In fact, the certain "horror of femininity" that typifies Hamlet's love relation to Ophelia suggests that if Hamlet is the drama of his fading desire, then Ophelia becomes the only representation of this repudiation (of desire). Consequently, Ophelia is "at this point the phallus, exteriorized and rejected by the subject as the very symbol of the rejection of his desire" ("Desire" 36).

The third way in which Hamlet sees Ophelia as the object that causes his desire is elicited in the scene of the graveyard where he pronounces: "I loved Ophelia. Forty thousand brothers could not with all their quantity of love makes up my sum. What wilt though do for her?" (5. 1. 128). According to this third paradigm, it 
can be witnessed certain reintegration of the object ( $\alpha$ ) that was "won back at the price of mourning and death" ("Desire" 36). Because of her irremediable death, Ophelia is "reincorporated" as Hamlet's object of desire. For Lacan, the graveyard scene is directed towards that furious battle at the bottom of the tomb in which the object of Hamlet's desire is in fact a dead object-Ophelia-who makes him a subject capable of desiring something that is now radically unattainable: "Only insofar as the object of desire has become an impossible object, can it become once more the object of his desire. [...] the obsessional neurotic sets everything up so that the object of this desire becomes the signifier of this impossibility" ("Desire" 36). According to Lacan, Hamlet desires as an obsessional neurotic in so far he can only desire at the very crossroads of imminent life and death, right in the premises of impossibility.

The horror of feminity is installed along the play according to the establishment of a frontier between the characters of Ophelia, the virgin, and Gertrude, the incestuous whore. Both female characters embody the drama of the feminine object trapped in the snare of masculine desire insofar as both women are, at the same time, the object and the hallmark of desire-small object (a), but also the phallus. In fact, the object of Hamlet's desire can become his object of desire to the extend that that object is lost, absent and purloined. Lacan affirms that "the very structure at the basis of desire always lends a note of impossibility to the object of human desire" ("Desire" 36). As seen before, the structure of this object is the phallus itself.

Therefore, the only way a subject can accept and process his object of desire is through loss and mourning. In a way, the enigma of Hamlet is also set as a drama of mourning and loss. After the graveyard fight with Laertes, Hamlet says: "But sure the bravery of his grief [Laertes] did put me into a tow'ring passion" (5. 2. 134). In this sense, the death of Ophelia releases a gap, a hole that is opened in the site of the Real. Hamlet introduces this relationship between death and emptiness/loss when he is in the graveyard for Ophelia: "Imperious Caesar, dead and turned to clay, might stop a hole to keep the wind away, O, that that earth which kept the world in awe should patch a wall t'expel the winter's flaw [wind]!" (5. 1. 126). In fact, Hamlet stands as a drama about what really endures when the symbolic order collapses. The main collapse abides in the play as Hamlet's failure to mourn, that is, his absolute failure to mourn the loss of the phallus.

Ophelia's death as well becomes a ritual sacrifice for Hamlet in expiation of the un-mourned loss of his father which "attempts to institute a lack that can be adequately mourned" ("Desire" 39). The object of desire is then constructed through mourning and death. The real object of desire is consequently "structurally" dead so the subject can only desire when the object is absent, fundamentally "dead." Here desire does not mean "yearning" but "nostalgia" for the adrift object. In the end, the phallus is that primordial mourned object whose loss is repeated in all forthcoming subjective experiences of lack, mourning, and psychical grief. Hamlet is certainly a play where "all anyone talks about is mourning" so the phallus, as a signifier is evoked throughout: "[...] the phallus is everywhere 
present in the disorder in which we find Hamlet each time he approaches one of the crucial moments of his action" ("Desire" 49).

Definitely, Hamlet stands as a tragedy of desire. Hamlet himself exclaims this to Horatio: "You, as your business and desire shall point you, for everyman hath business and desire such as it is, and for my own poor part, look you, I'll go pray" (1. 5. 32). This illustrates how Hamlet's business is continually molded by his subjection to the desire of the Other and its signifier, the phallus: First his mother, then Ophelia. This subjection is finally resolved at the moment of death when he is being liberated from the impositions of law and language, and henceforth, he becomes an individual subjected to/by the desire of the capitalized Other.

In the game of desire, the phallus cannot be eliminated because, as Hamlet's father-the Ghost-is nothing and does not exist. However, Hamlet, the drama, exemplifies the perplexity of all human beings: We all are trapped in the webs of desire and cannot abscond from them. The enigma of Hamlet is our own enigma as well; that is, we are subjected beings, in lack, fundamentally divided, always desiring the object that does not exist-the phallus. For instance, in the case of Ophelia, Hamlet does not want to accept he loves her when she is alive. He declares it to Laertes when she is already dead, in the cemetery, deep in the dying hole. Hamlet desires Ophelia given that she is not there anymore, and she is absent. As stated before, lack opens up the road to desire. Lack makes us desire. That object which causes desire, that petit object $(a)$ that originates desire is the phallus, that is, the primordial signifier. That is why, as Lacan proposes, for Hamlet, Ophelia is O'Phallus.

\section{Bibliography}

Freud, Sigmund. The Interpretation of Dreams. The Standard Edition of the Complete Psychological Works of Sigmund Freud. Vol. 4. Trans. James Strachey. London: Hogarth Press, 1953. 1-630. Print.

Lacan, Jacques. "Desire and the Interpretation of Desire in Hamlet." Literature and Psychoanalysis: The Question of Reading Otherwise. Ed. Shoshana Felman. Baltimore: John Hopkins UP, 1982. 11-52. Print.

"The Signification of the Phallus." Écrits: The First Complete Edition in English. Trans. Bruce Fink. New York and London: W.W. Norton, 2006. 575-84. Print.

Desire and its Interpretation. The Seminar of Jacques Lacan. Book VI. Web. 25 June 2014. <http://www.lacaninireland.com/web/wp-content/ uploads/2010/06/-THE-SEMINAR-OF-JACQUES-LACAN-VI.pdf>

Muller, John P. "Psychosis and Mourning in Lacan's Hamlet." New Literary History 12.1 (1980): 147-165. Print.

Rabaté, Jean-Michel. "Hamlet and the Desire of the Mother." Jacques Lacan. Psychoanalysis and the Subject of Literature. London: Palagrave, 2001. 5468. Print. 
"Psychoanalysis Applicable and Inapplicable." The Literary Lacan: From Literature to Lituraterre and Beyond. Ed. Santanu Biswas. London: Seagull Books, 2012. 51-85. Print.

Reinhard, Kenneth and Julia Reinhard Lupton. "Hamlet's Flesh: Lacan and the Desire of the Mother." After Oedipus. Shakespeare in Psychoanalysis. Colorado: The Davis Group, 2009. 43-66. Print.

Schneiderman, Stuart. Jacques Lacan: The Death of an Intellectual Hero. Cambridge, Massachusetts: Harvard UP, 1983. Print.

Shakespeare, William. (1603). Hamlet, Prince of Denmark. Ed. Sylvan Barnet. New York: Signet Classics, 1998. Print.

Sharpe, Matthew. "To Be, or Not: Lacan and the Meaning of Being in Shakespeare's Hamlet." The Literary Lacan: From Literature to Lituraterre and Beyond. Ed. Santanu Biswas. London: Seagull Books, 2012. 89-116. Print. 